Teaching \& Learning (2013) 7(3), 29-46

\title{
Expanding Educators' Awareness of Youth Homelessness through Critical Dramatic Inquiry
}

\author{
AMANDA C. WAGER \\ University of British Columbia \\ KARI-LYNN WINTERS \\ Brock University
}

\begin{abstract}
This article explores how educators use drama in conjunction with critical inquiry to support students' sustained notions of equity and engagement. After participating in a Mantle of the Expert (Heathcote \& Bolton, 1995) - a participatory drama in education inquiry, eleven educators enrolled in a university drama course gained a broader awareness of poverty, enabling them to refute stereotypes of homeless youth. Findings demonstrate that critical dramatic inquiry has the potential to bridge cultural divisions and increase group awareness of social justice initiatives. Additionally, for many of the participants, the Mantle opened their eyes to a new pedagogy - a method and practice of teaching that was both critical and participatory.
\end{abstract}

\section{Introduction}

When I was in elementary school I was not aware that there was a class system. I just basically thought I grew up in a neighbourhood and that's what all neighbourhoods were like. It wasn't until university that I noticed that there were many different levels of society. (Courtney ${ }^{1}$, interview, July 31, 2009)

In the summer of 2009 , we (the authors of this paper) attended a drama institute led by the late drama education pioneer, Dorothy Heathcote. We gained understandings about how to design drama classrooms in ways that feel equitable and safe; and at the same time we learned more about other research studies and projects that were happening in the drama education field. Findings from these studies/projects (Gallagher, Wessels, \& Ntelioglou, 2012; Rogers, Winters, La Monde, \& Perry, 2010; Winters, 2009) suggested that dramatic inquiry has the potential to be a safe space where critical exploration can take place, and where students can work together to

\footnotetext{
${ }^{1}$ All names are pseudonyms.
} 
better understand cultural divisions. Given these findings, and the growing evidence that suggested Courtney's perspective (see the quote above) was shared by others enrolled in the course, we decided to design a critical and participatory, in-class dramatic inquiry that would magnify social class distinctions in our region. Specifically, we wanted to explore how educators enrolled in a university drama education course might use critical dramatic inquiry to inform their notions of equity, and expand their pedagogies. Furthermore, we wanted to offer these university students models for drama education that they could use in their own classrooms to address these and other relevant social issues.

The following questions guided our research: (1) In what ways might critical and participatory dramatic inquiry increase these educators' awareness of current socio-cultural issues (i.e., youth homelessness), while at the same time help learners gain understandings of their own socio-cultural identities? (2) How can dramatic inquiries contribute to the ways in which educators and their future students co-construct pedagogy in educational contexts? (3) Why might dramatic inquiry matter within classroom settings?

\section{Theoretical Frameworks and Practices}

Our theoretical framework is primarily informed by the scholarly works of drama-ineducation pioneers like Dorothy Heathcote, Gavin Bolton, and Augusto Boal. Their practices (i.e., Mantle of the Expert and Theatre of the Oppressed) explore the experiences of marginalized peoples. Specifically, these practitioners examine the existing historical, social, and political fabric that characterized dominant societies — posing questions and developing students' selfawareness.

\section{Mantle of the Expert}

Drawing on the knowledge and experience of all people in the classroom, instead of relying on the authority of the teacher, Heathcote's (Heathcote \& Bolton, 1995) Mantle of the Expert provides a space where students position themselves as experts in any field of study. Within these roles, students examine real-life problems and construct new knowledge together. Inside classrooms - often where participatory drama contexts are explored — students and teachers share the power, making learning relevant and more equitable. 
O’Neill (1995) describes Mantle of the Expert as "an approach that is purposeful, dialogic, emancipatory, and metaphoric" (p. vii). The goal of the Mantle is not to teach specific information or lead participants toward a predetermined goal. Rather, Mantles are respectful spaces where all participants have opportunities to construct and share perspectives. Heathcote (1995) adds that this kind of work "takes time and infinite gradations of perspective, each one chewed over ... as a deliberately task-orientated action" (p. 22).

\section{Theatre of the Oppressed}

Inspired by renowned educator, Paulo Freire (1970), Augusto Boal (1979) developed the Theatre of the Oppressed approach (1979/2008) in response to the need for political and economic change in rural Brazil. Boal's goal was to create a "forum" for the oppressed to consider various staged options, before confronting these issues in real life. To do this, Boal developed improvisational activities, workshops and plays that reach a moment of crisis without offering a solution. Within the Forum Theatre technique, the spect-actors (spectators + actors), or active audience members, are asked to intervene on stage to help the characters solve the problem (Boal, 2002). They do this by replacing the actor, resuming the action and introducing an intervening viewpoint into the scene: "... far from being a witness, the spect-actor is, or must do his utmost to become, the protagonist of the dramatic action" (Boal, 2002, p. 255). Boal's vision, as summarized by Schutzman and Cohen-Cruz (1994) is:

embodied in dramatic techniques that activate passive spectators to become specactors - engaged participants rehearsing strategies for personal and social change. Although founded in theatrical exploration, the techniques, all based on transitive learning and collective empowerment, are not limited to the stage; educators, political activists, therapists and social workers devoted to critical thought and action have adapted the work to address issues ranging from racism and sexism to loneliness and political impotence. (p. 1)

A related technique of Theatre of the Oppressed is called Image Theatre. "Freeze life in any moment. That is an image" (Diamond, 2007, p. 92). Within Image Theatre, specific issues are addressed through frozen images created by participants, who then contribute their 
interpretations of the image's meanings through various forms, such as stating thoughts, adding bodies in the image, and changing the positions of people in the image (Boal, 1995). Image

Theatre as a research technique has been widely used with groups of people from various racial, economic, ethnic, and social backgrounds (Schutzman \& Cohen-Cruz, 1994; Rohd, 1998). Both Forum and Image Theatre are a means by which a community's collective story and the power dynamics within that community, can be created and explored in front of an audience or in a workshop, classroom, or theatrical setting.

\section{Contemporary Critical Drama Education Research}

Acknowledging the profound contributions of these drama pioneers, contemporary researchers such as Rogers and Winters (2010), Gallagher et al. (2012), and Conrad (2004), extend the critical potentials of drama. These arts researchers argue that participatory dramatic practices are viable frameworks, through which education can be designed, and youth can be motivated, to think critically about equity. Specifically, they explore the participatory and critical ways marginalized populations construct their identities, make themselves visible, and refute stereotypes.

Rogers and her teams of researchers (i.e., Winters, La Monde, Perry, Wager, Schroeter) explore identity constructions within homeless communities, to better understand participants' subjectivities and use of satire. Through multimodal representations (e.g., play scripts, poems, drama, art, photography, film) of their study participants, they demonstrate that homeless youth negotiate their own identities by assuming and assigning subject positions, ultimately creating more nuanced types of critical discourse (Rogers \& Winters, 2010).

In one of Gallagher's research projects (alongside Wessels \& Ntelioglou, 2012), she brought homeless youth and affluent theatre audiences together in a downtown Toronto theatre, in order to study equity and power. Addressing questions of subjectivity, space, and representational modes in a diverse urban context, Gallagher and her colleagues also demonstrate that drama helps to construct study participants' identities. For drama gave participants (both homeless youth and affluent audiences alike) the opportunity to be simultaneously inside and outside of economic barriers, while at the same time "circling [their own] histories and class structures" (Grumet, as cited in Gallagher, 2001, p. xi). 
Conrad and Kendal (2009) believe that identities are consistently constructed, and that attitudes about youth can be altered through arts-based practices like drama. Drawing on this premise, they develop workshops to educate service providers, while investigating the inherent resilience of youth, in order to best meet the needs of the high-risk populations they serve. Youth in their study are offered opportunities to voice opinions and to refute assumptions being made about them.

Critical drama research studies (Medina, 2005; Wager, Boone, Benallie, Nimmon, Goulet, \& Coburn, 2009; Winters \& Rogers, 2006) use drama to question power and sociocultural values in consciousness and society. Researchers argue that the innate nature of drama allows populations to see themselves within their situational contexts, while at the same time, to develop critical thought and cooperative action (Shor, 1992).

\section{Positioning theories}

In addition to more stable notions of cultural identity (i.e., class, ethnicity, age), we also draw on a critical positioning theory that articulates the flexible ways that humans assume and assign subject positions — based on their own subjectivities — within the narrative spaces of applied theatre (Davies \& Harré, 1990). For example, at various times during our Mantle, the study participants assume the temporary and imagined position of "experts." And yet, at other times they position themselves, or are positioned, as learners, who do not understand all the nuances of homelessness. These flexible positions that the university students take on/assign, shape the meanings they construct within and beyond the drama classroom.

Drama spaces invite a climate of critical synthesis, as opposed to a space where one party transforms the other (Freire, 1970). In this way, dramatic inquiry gives learners opportunities to assume and assign flexible subject positions — imagined roles — and at the same time, to be critical about the worlds in which they live (Holland, Lachicotte, Skinner, \& Cain, 2001). Within these yielding spaces, participants embody, dialogue about, and develop narratives to guide their decisions and actions (e.g., a woman notices a pregnant teen is homeless; she immediately feels more sympathy and offers a coin to the teen, because this woman also positions herself as a mother). Ultimately, these subject positions help participants create images and dialogues, which in turn become the focus of collaborative meaning making (Davies \& Harré, 1990). 


\section{The Research Study}

It is important to note that both authors of this paper have worked in impoverished communities, and have researched the ways that homeless populations have been marginalized, or worse, stereotyped in, and beyond, educational settings (Rogers \& Winters, 2010; Wager et al., 2009). Combining this cultural knowledge with the expertise they gained at the 2009 Dorothy Heathcote Summer Drama Institute at the University of Victoria, they created a Mantle they hoped would extend their university students' understandings, through dramatic inquiry of what it means to be homeless.

The study was located within a classroom at a Western Canadian university. The majority of the eleven study participants ( 8 of the 11$)$ in this follow-up study were already elementary and secondary teachers, who were taking a summer course in the field of drama in education. Most of the participants were female (9 of the 11). All were between the ages of 20 and 50 years old, and lived close to an urban area on Canada's west coast. To the best of our knowledge, none of the participants had ever been homeless. Permissions were granted by all of the study participants to use their sample documents, to make observational notes, to record their interviews, and to photograph their process within the drama.

\section{Method}

To describe the mantle would be to say that we researched and read articles on [local] street youth. We learned a background on what we were going into and then each of us decided what voices were important to us. We broke into groups and embodied that experience of those voices and listened to others opinions. We created scenes of what the neighbourhood looked like, created the neighbourhood and a scene of what it looked like inside the safe houses. We had a community meeting that involved each of us taking on a character within a neighbourhood that a safe house might be put. My name was Silver and I was a street youth who lived in one of the community parks and I talked about how the safe house had helped me in another neighborhood. (Jordana, interview, July 21, 2009)

Prior to the Mantle, the university students were asked to read an article, written with street-entrenched youth (Elliot, 2008), about the closings of the underage safe houses. The article 
draws upon an original theatre production, Surviving in the Cracks, co-created with the first author alongside seven formerly street-entrenched youth, and in collaboration with Vancouver Youth Visions Coalition and UBC's Partnerships in Community Health Research (Wager et al., 2009). Specifically, this article demonstrates power inequities and the marginalization of impoverished youth. Furthermore, it shows that early adolescent youth entrenched in street life are particularly vulnerable, often turning to drugs and prostitution for survival (Unger, Simon, Newman, Montgomery, Kipke, \& Albomoz, 1998). The discussion around the article served as a forum for the university students, giving them opportunities to explore issues around harm reduction and stereotypes, and at the same time, illustrating that theatre can provide a powerful space for engaging in social and political issues through action and voice.

Following the discussion, participants observed a documentary film trailer, Surviving in the Cracks (Masuda, 2011), based on scenes from the original theatre presentation (mentioned above). In the trailer, specific communities identify, examine, and take action, offering personal perspectives about the closures of the Vancouver underage safe houses - a home where many of the cast members had lived prior to the closings.

What followed was a three-day Mantle of the Expert, regarding the closings and imagined re-openings of underage safe houses within a local neighborhood. This Mantle opened with a community council meeting. The first author (in role as the leader of the municipal council) read a letter to the community members, explaining that the Ministry was considering opening an underage safe house within their neighbourhood. The university students (in role as community members) expressed their opinions about the situation. Before the community meeting adjourned, the first author informed the members that in a few days, representatives from the Ministry would be visiting to listen to their opinions.

Over the next few days, the university students, using artifacts they brought in, created Image Theatre scenes of underage safe houses (see Figure 1), and of youth living on the street (see Figure 2), as well as a map of their community (see Figure 3). 
Expanding Educators' Awareness

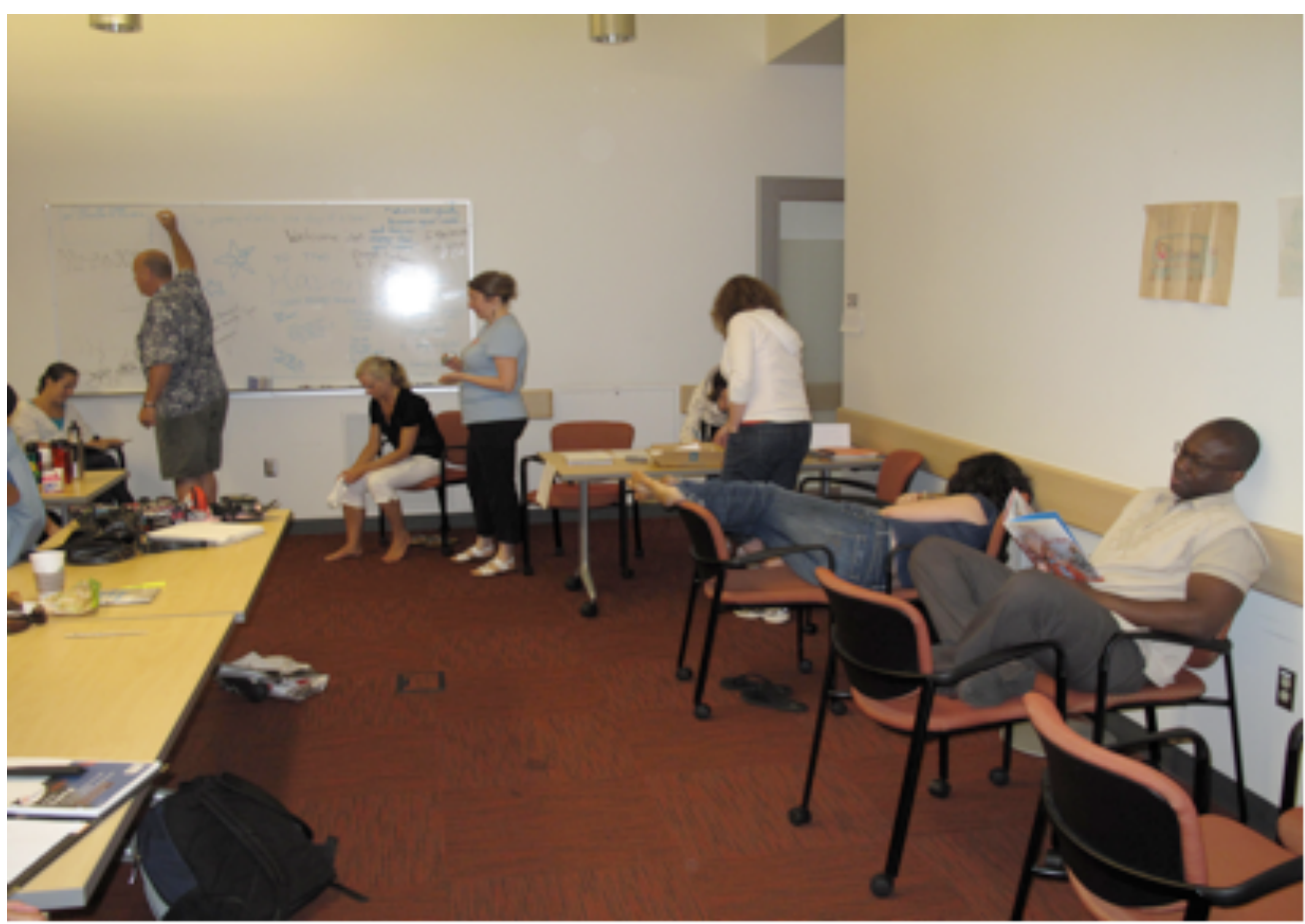

Figure 1: Image Theatre of an underage safe house

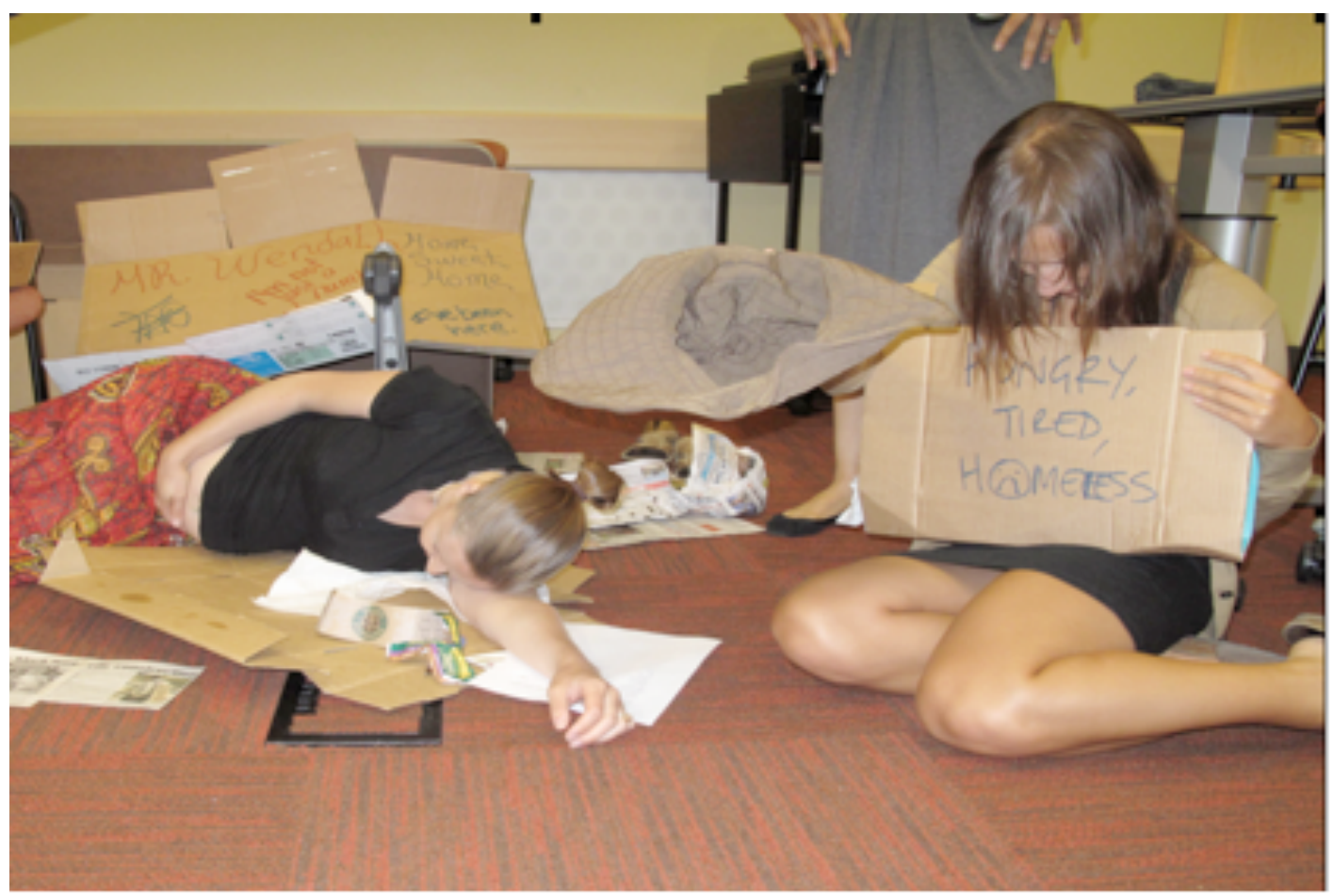

Figure 2: Image Theatre of Street-entrenched Youth 


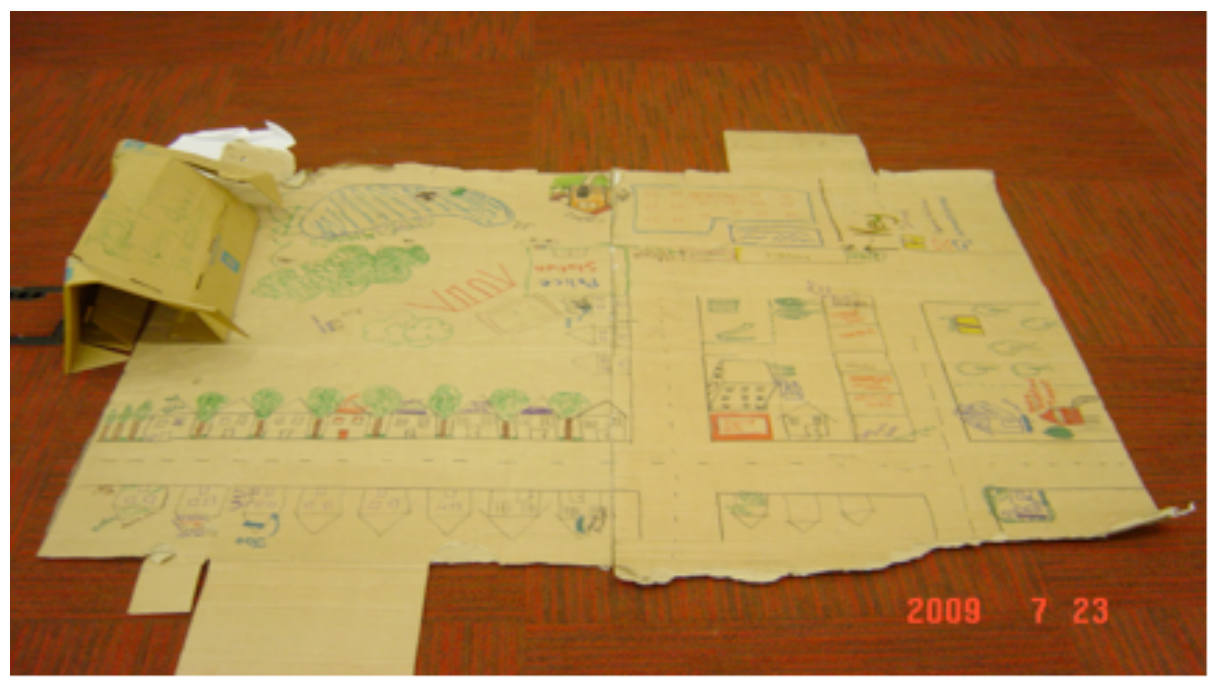

Figure 3: The community map

On the final day, the second author and two additional faculty members became "experts" in our Mantle. They represented governmental Ministry members; their job was to interview different community members about their imagined perspectives as community members. A final council meeting was held on the last day where members debated — for or against the reopening of the safe house in their community. From these perspectives, the participants brainstormed their narrated identities, in order to write letters (in role) to the Ministry, expressing their characters' perspectives of homelessness (See Figure 4).

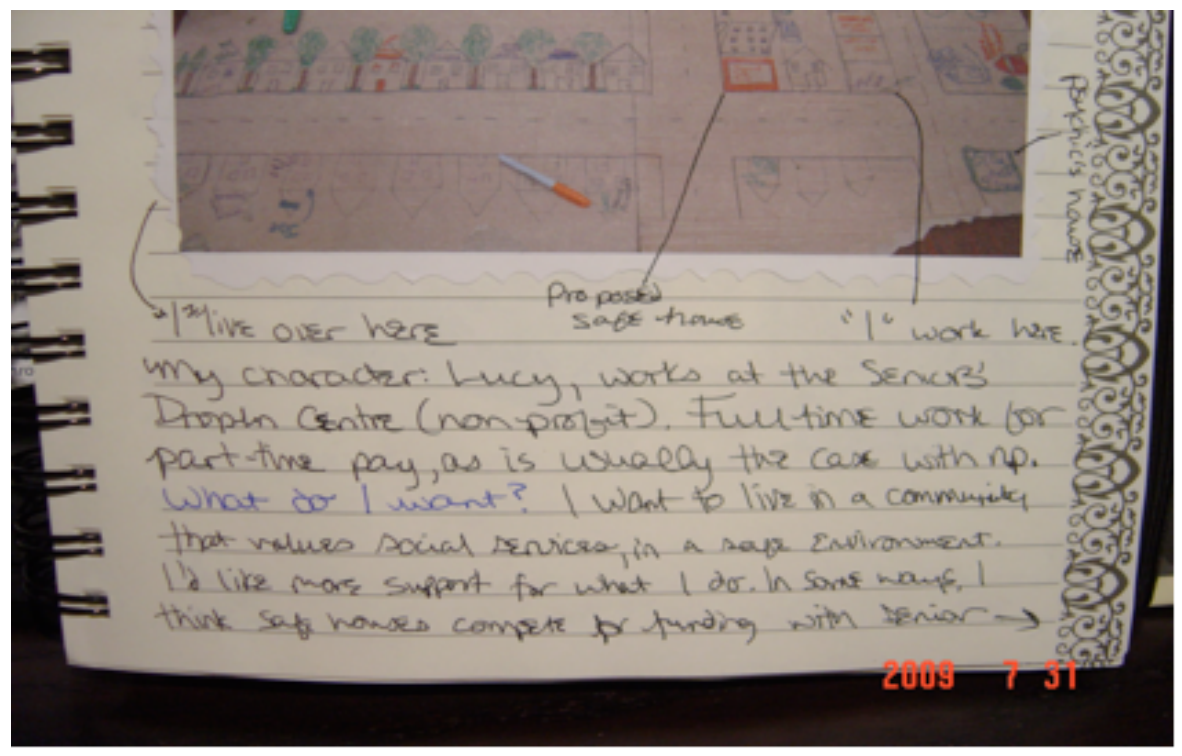

Figure 4: Brainstorming Character Perspectives 
Throughout the Mantle, the authors - as facilitators-in-role — guided the participants through various questioning sessions, participatory multimodal activities (e.g. guided tours, mapmaking, council meetings), and role-playing. We also took on roles within the narrative, made suggestions, and offered critiques. Our intent was to allow learning to surface in participatory ways, while at the same time facilitating the dramatic inquiry. Exploring topics and ideas lead the participants to authentically engage with and think about their experiences. The Mantle's format was open enough to invite a diversity of perspectives, yet focused enough to pinpoint the issues of homelessness. By creating an open space for scene work, performance, and critical exploration, everyone seemed engaged and eager to participate. Moreover, they wanted to record their dramatic inquiry through journaling, in order to "collectively examine and analyze causes of specific issues, explore avenues of potential action, and create an opportunity to take such action" (Conrad, 2004, p. 7).

Following the Mantle, the university students voluntarily participated in two optional focus groups (one with two study participants and the other with seven), and one individual interview. All focus groups and interviews were semi-structured, audiotaped, and lasted approximately 30 minutes. These discussions shed even more light on their perspectives of homelessness, and what it might be like to use dramatic inquiry in upper elementary or secondary classrooms.

Our goals in conducting these focus groups and interviews were to explore the impact the Mantle had on these university students, and also - since many were already practicing teachers

- to hear their thoughts on what it might be like to try the Mantle with their own elementary and secondary students. This included their opinions on how to gain trust with early adolescents, in order to do a more in depth Mantle during a brief period of time.

\section{Data Analysis}

Data sources included field notes, journal entries, photos, and interview and focus group transcriptions. Additionally, the first author documented all activities by constructing a Task Sheet (Table 1), utilizing Heathcote's Task Sheet template from the 2009 summer Drama Institute. 
Table 1: Heathcote's Mantle of the Expert Task Sheet

\begin{tabular}{|l|l|l|l|l|l|}
\hline TASKS & DEMANDS & PURPOSE & PREPARATIONS & DEVICES & OUTCOMES \\
\hline & & & & & \\
\hline
\end{tabular}

The task sheet not only enabled us to design the Mantle, it also gave us a tool to recognize emerging patterns in the data and to analyze it.

\section{Findings}

The following three themes were underscored:

- Increased awareness of multiple perspectives;

- Co-constructions of pedagogy in an educational context; and

- Dramatic inquiry matters.

Each of these themes speaks to our broader research questions and is explored below.

\section{Increased Awareness of Multiple Perspectives}

Embodying narrative through the Mantle laid the groundwork for multiple perspectives, and allowed for the creation of a safe, but critical space. For instance, we found that by using the Mantle as a springboard for discussion, participants shared their understandings of homelessness in relation to their own subject positions and opinions. During a focus group, Felicita, a Black non-education student from Sierra Leon, explained that:

I guess you hear [about youth homelessness], you sympathise ... I guess I remember one activity where we had to get people on your side and I started to feel really passionate about it and then I started to feel really hypocritical. You are so removed from it. The most interesting part of the Mantle was when we were walking around and trying to talk people into what you think. When we took that time to convince people, people were talking, people were saying what they think and that forced me to think that this is real. (focus group, July 31, 2009)

Participants also discussed how this participatory dramatic inquiry increased their awareness of current issues (e.g., homelessness, safe houses), and at the same time, helped these learners gain understanding of their own socio-cultural identities. For example, Courtney noted, “... people 
have to be educated and many people aren't so they view this [youth homelessness] ignorantly because they don't realize the reasons why people are on the street. They need to realize that people need support" (interview, July 31, 2009). While there was a great deal of positive feedback about the Mantle, some students were more critical of the process. For example, Jordana - a White art teacher candidate — stated that "Mantles could be confusing at first, because there are so many perspectives to consider," but ultimately suggested that these layered dimensions show multiple perspectives; "I think every student comes to a Mantle with their own experiences and that is what makes it so powerful" (interview, July 31, 2009). Manuel too, a Black grade 6/7 elementary teacher with a focus on administration, suggested that in order to gain trust and create a comfortable atmosphere with high school students, it might be helpful to "Ask the students first - what do they know about this topic? What are some things you think about street youth?" (focus group, July 31, 2009).

Researchers who use critical drama pedagogies and work with marginalized populations, often touch on this important idea - that all participants come to the study with different assumptions, social positions, beliefs, and feelings about any given issue. Rogers and Winters (2010) clarify this point, stating, "Street culture is itself complex and multifaceted....[r]ather than a homogenous street youth culture, [groups are] made up of individuals and subgroups, each constructing differing and particular kinds of identity positions or subjectivities based on their local situations, interests/beliefs, projects, and goals" (p. 94). Working in universities can be similar, as it is important for researchers and study participants to explore the multiple positions people assume and assign before, through, and after each Mantle, in order to better understand and ultimately refute stereotypes.

Concerns were also raised with some of the stereotypes that were brought forth. As the Mantle emerged, homelessness itself came to be seen less as a 'fixed identity' among the university students, and more as a 'temporary situation' — often as how homeless youth identify their situations. Aware of this distinction, many of the participants felt that this drama inquiry had the potential to provoke them to make changes in their own teaching practices, and could imagine it giving their students agency. Bella — a White art/English secondary teacher candidate - explained this idea in her interview: 
A Mantle is looking at a local issue and giving kids the opportunity to get involved in an issue...to feel like, "Look I can do something!" That's how change happens. Why wait for someone else to do it? I can do it! (interview, July 31, 2009)

Heathcote and Bolton (1995) state that Mantles are open spaces for agency through fictional contexts, because the teacher and students share power together, and draw on the knowledge and experience of all people in the classroom. As we created and presented different perspectives of the issue through multiple modalities (e.g., pictures, photos, scenes, tableaux, scripts), we saw a broader picture of reality, and we collectively began to imagine ways to "move beyond boundaries, to transgress" (hooks, 1994, p. 207).

\section{Co-constructions of Pedagogy in an Educational Context}

Several participants stated that the participatory and dramatic nature of the inquiry would be a welcomed addition into their teaching practices. For instance, Jordana explained, "As a teacher, I think the Mantle impacted me profoundly...it feels like I have been given a gift, a vehicle in which I can give students in my classroom" (interview, July 31, 2009). Courtney - a White experienced ESL teacher — adds, "It [the Mantle] takes [students] away from the 'we' and the 'them' - and makes it an US" (interview, July 31, 2009). Both of these participants saw the Mantle as an opportunity to approach difficult topics with their students. For them, the Mantle provided a space that students could get involved.

Meanwhile, other participants were more cautious. For example, Bella states, "I feel like one thing that I feel uncomfortable with is having the secondary students take it seriously. Maybe they will be too cool to do it. Setting an environment of trust would be really important. This would be my concern of bringing it to high schools" (focus group, July 31, 2009). Derek a South Asian secondary teacher — adds, “The biggest barrier isn't the kids, or what's appropriate, it's the parents." These educators were realizing that drama could be not only a critical space — but also a space that demands a careful, sensitive approach (interview, July 31, 2009).

Other concerns with bringing an issue-based Mantle to the classroom, were in relation to time and trust. Courtney picked up on this idea, stating, "Time must be created in order to 
develop trust and a level of respect. Inside the Mantle, we kept hearing that it's ok to slip up your ideas aren't going to be put down" (interview, July 31, 2009). As instructors and researchers with backgrounds in drama, we understood that time is essential for gaining trust. We also knew that if we wanted the Mantle to be both creative and profound, we needed to create a space where the participants could make mistakes and not be penalized.

Some of the participants suggested that we could improve our Mantle if we handed out anonymous questionnaires prior to our inquiry. In this way sensitive questions could have been addressed (e.g., Do you know anyone that has been kicked out? Have your parents ever threatened to kick you out? Do you know about poverty? Have you ever lived on the streets?). Another suggestion was to invite street youth to the university for an open discussion with university students - possibly destroying certain barriers and building trust. However, for several reasons, some ethical and some financial, this suggestion could not become an actuality.

\section{Why Dramatic Inquiry Matters?}

The arts and theatre make us more human; they teach us how to sympathize and be compassionate (Jonothan Neelands' summer course, class notes, 2011). Within safe and carefully constructed spaces, participants experience "what if" questions, while discovering how to approach productive tensions and to acknowledge others. Nora - a White International Baccalaureate teacher of five years — noted that dramatic inquiries such as Mantles, "instigate actions, so that students say now it's in our hands" (interview, July 31, 2009). The Mantle becomes a call-to-action emphasizing that drama not only motivates people to learn, it also allows people to be regarded as conscious beings (Boal, 1979). Freire (1970) suggests that a key element in creating change requires a focus on the subjective, or one's own perception and experience of the world. Dianne - a South Asian fine arts secondary teacher — speaks to this idea, stating, "Art gives students a purpose...my grade 10 students [might ask] 'so what can we do with this now?"” (interview, July 31, 2009).

Below, Bella suggested that by using drama, students engage — creating a sense of being "wholly involved" and "wholly committed" — to the unknown or the unfamiliar (Smithrim \& Upitis, 2005). 
You are forced to use different perspectives, those that you might not have necessarily chosen for yourself. Typically, kids might gravitate towards something that they know... something that's comfortable for them, but it might be good to get them out of their comfort zone. (Bella, interview, July 31, 2009)

This is because each participant brings a set of beliefs, actions, and subject positions to the Mantle, offering unique and informed perspectives about an issue.

Some of the participants suggested that the Mantle offered new opportunities to explore questions, create knowledge, and express understandings that may not be accessible or representable through other means (e.g., discussions, essays). Courtney states:

Too many people feel that they lack education on the subject. That they are ignorant or unqualified to express their opinions or be an agent of change. Yet, Mantles grant students permission to position themselves as experts and to truly understand that there are reasons why people are where they are. And that sometimes these people need help and support. (interview, July 31, 2009)

She goes on to argue that critical dramatic inquiry not only encourages "practical knowing" of an issue, it also has the potential to help students embrace diversity, and to benefit larger communities (e.g., local, national, global), by encouraging mutual respect towards others and by inspiring students to make a difference.

\section{Conclusion}

In Vancouver alone, an estimated 150 new youth become homeless every year (Social Planning and Research Council of BC, 2008). These 150 youth are in addition to the 700 youth who are already homeless or at risk of being homeless (Kraus \& Woodward, 2007). In spite of this pervasive problem, there is limited research on how to raise adolescent youth awareness in schools about the consequences of living on the streets. Through participatory critical dramatic inquiry, pre-service and practicing teachers learned about marginalized populations in their communities, became aware of class discrimination, and were able to refute class stereotypes. They gained multiple perspectives on what is equitable, while at the same time they co- 
constructed pedagogic knowledge, and felt inspired to take drama practices into their own classrooms.

Inspiring educators and their students to make positive change in their local, national, and global communities, requires interdisciplinary teaching methods that span cultural divides, incorporate youth voices, and ultimately help build safe spaces, where individuals can creatively and critically build community. Participatory and critical dramatic inquiry recognizes that no single person has the whole answer, but rather everyone has something important to contribute; in other words, the thoughts and perspectives of others can enrich every person's thinking. Using critical dramatic inquiry with university education students added to this contribution; while the students learned the power of using the Mantle and Theatre of the Oppressed techniques, they also expanded their awareness of social class systems and youth homelessness. It is our hope that these educators will use critical dramatic inquiry in their own classrooms to potentially encourage action with their future students, and in their own school communities.

\section{Acknowledgements}

The authors would like to extend their gratitude to the street youth and co-authors from Surviving in the Cracks, to the participating university students in this study for all their energy and insights, to George Belliveau for his help with the completion of behavioural ethics, and to Dorothy Heathcote for guiding us (and so many others) through a powerful experience, giving us opportunities as educators to understand the potential a Mantle can offer - you are greatly missed.

Amanda C. Wager is a doctoral student at the University of British Columbia. During her eight years experience as an educator, she has used drama and theatre to nurture youth self-expression in her diverse classrooms. She has presented and published on her research interests, which include feminist/critical/public pedagogy, applied theatre, research-based theatre, and additional language learning. Amanda's passion lies in building safe spaces, in which individuals can creatively and critically co-construct pedagogy in an educational context.

Kari-Lynn Winters is an award-winning children's author, playwright, educator, and academic scholar. With a background in applied theatre and education, she integrates the arts and critical participatory learning across all subject areas. Kari-Lynn is an assistant professor at Brock University. Her research interests include drama, children's literature and multimodal authorship. More information about Kari-Lynn can be found on her website, www.kariwinters.com.

\section{References}

Boal, A. (1979/2008). Theatre of the Oppressed. (E. Fryer, Trans.). London, UK: Pluto Press. Boal, A. (1995). Rainbow of desire. (A. Jackson, Trans.). London, UK: Routledge. 
Boal, A. (2002). Games for actors and non-actors ( $2^{\text {nd }}$ ed.). London, UK: Routledge.

Conrad, D. (2004). Exploring risky youth experiences: Popular theatre as a participatory, performative research method. International Journal of Qualitative Methods, 3(1), 12-24.

Conrad, D., \& Kendal, W. (2009). Making space for youth: iHuman Youth Society \& arts-based participatory research with street-involved youth in Canada. In D. Kapoor \& S. Jordan (Eds.), Education, participatory action research and social change: International perspectives (pp. 251-264). New York, NY: Palgrave Macmillan.

Davies, B., \& Harré, R. (1990). Positioning: The discursive production of selves. Journal for the Theory of Social Behaviour, 20(1), 43-63.

Diamond, D. (2007). Theatre for living: The art and science of community-based dialogue. Victoria, BC: Trafford Publishing.

Elliot, S. (with Boone, D., Coburn, T., \& Goulet, J.). (2008). Underage youth safe house project: Summer 2008. Unpublished paper, Vancouver Youth Visions Coalition in collaboration with Partnerships in Community Health Research, University of British Columbia, Vancouver, Canada.

Freire, P. (1970). Pedagogy of the oppressed. (M. Ramos, Trans.). New York, NY: Herder \& Herder.

Gallagher, K. (2001). Drama Education in the lives of girls. Toronto, ON: University of Toronto Press.

Gallagher, K. (2007). The theatre of urban: Youth and schooling in dangerous times. Toronto, ON: University of Toronto Press.

Gallagher, K., Wessels, A., \& Ntelioglou, B. Y. (2012). Verbatim theatre and social research: Turning towards the stories of others. Theatre Research in Canada, 33(1), 2443.

Godley, A. (2003). Literacy learning as gendered identity work. Communication Education, 52(3-4), 273-285.

Granger, P., Nixon, S., Wager, A., Frankish, J., Walker, L., Masuda, J., Dixon, J., Rock, J., \& Nimmon, L. (2008). Street youth revelations through ethnodrama. Vancouver, BC: The University of British Columbia, Office of Research Services, Behavioural Research Ethics Board.

Heathcote, D., \& Bolton, G. (1995). Drama for learning: Dorothy Heathcote's Mantle of the Expert approach to education. Portsmouth, NH: Heinemann.

Holland, D., Lachicotte,W., Skinner, S., \& Cain, C. (1998). Identity and agency in cultural worlds. Cambridge, MA: Harvard University Press.

hooks, b. (1994). Teaching to transgress: Education as the practice of freedom. New York, NY: Routledge.

Kraus, D., \& Woodward, J. (2007). The Vancouver youth options study. Eberle Planning and Research. Retrieved from http://vancouver.ca/commsves/housing/pdf/YouthHousingOptions.pdf

Masuda, G. (2011). Surviving in the cracks: A true story about a play with a purpose [documentary]. Canada: Masuda Media Ltd.

Medina, C. (2005). Discourse and ideology in writing in role: Critical discourse analysis as a tool for interpretation. Youth Theatre Journal, 19(1), 102-116.

New London Group. (2000). Multiliteracies: Literacy learning and the design of social futures. London, UK: Routledge.

O’Neill, C. (1995). Foreword in Heathcote \& Bolton's: Drama for learning: Dorothy 
Heathcote's Mantle of the Expert approach to education. Portsmouth, NH: Heinemann. Prentki, T., \& Selman, J. (2000). Popular theatre in political culture: Britain and Canada in focus. Portland, OR: Intellect Books.

Rogers, T., \& Winters, K. (2010). Textual play, satire, and counter discourses of street youth zining practices. In D. Alvermann (Ed.), Adolescents' online literacies: Connecting classrooms, media, and paradigms (pp. 91-108). New York, NY: Peter Lang.

Rogers, T., Winters, K., La Monde, A., \& Perry, M. (2010). Youth media production as new literacy practices: A play of genre, positioning and critique. Pedagogies, 5(4), 298-312.

Rohd, M. (1998). Theatre for community, conflict \& dialogue: The hope is vital training manual. Portsmouth, NH: Heinemann.

Schutzman, M., \& Cohen-Cruz, J. (Eds.). (1994). Playing Boal: Theatre, therapy, activism. London, UK: Routledge.

Shor, I. (1992). Empowering education. Chicago, IL: The University of Chicago Press.

Smithrim, K., \& Upitis, R. (2005). Learning through the arts: Lessons of engagement. Canadian Journal of Education, 28(1), 119-127.

Social Planning and Research Council of BC. (2008). Still on our streets... results of the 2008 metro Vancouver homeless count. Retrieved from http://www.metrovancouver.org/planning/homelessness/Homlessness\%20`1Docs/WEB 2008 Count Report FINAL Sept 15.pdf

Unger, J., Simon, T. R., Newman, T. L., Montgomery, S. B., Kipke, M. D., \& Albomoz, M. (1998). Early adolescent street youth: An overlooked population with unique problems and service needs. Journal of Early Adolescence, 18(4), 325-348.

Wager, A. C., Boone, D., Benallie, A., Nimmon, L., Goulet, J., \& Coburn, T. (2009). Surviving in the cracks. Unpublished script, Vancouver Youth Visions Coalition in collaboration with Partnerships in Community Health Research, University of British Columbia, Vancouver, Canada.

Winters, K. (2009). Authorship as assemblage: Multimodal literacies of play, literature, and drama. (Doctoral dissertation). Retrieved from https://circle.ubc.ca/handle/2429/21723

Winters, K., \& Rogers, T. (2006). The Antigone Project: Exploring the imaginative, active, and social dimensions of drama, print literacy, and media. In T. Crumpler, J. Schneider, \& T. Rogers (Eds.), Process drama and multiple literacies: Addressing social, cultural, and ethical awareness. Portsmouth, NH: Heinemann. 